\title{
Third Cinema Theory: New Perspectives
}

\author{
By Nicola Marzano
}

Fall 2009 Issue of KINEMA

THIRD CINEMA THEORY: NEW PERSPECTIVES

\section{Synopsis}

This article tries to address established notions of Third Cinema theory and its film makers from developing and postcolonial nations. The 'Third Cinema' movement called for a politicised film-making practice in Africa, Asia and Latin America, since its first appearance during the 60s and 70s taking on board issues of race, class, religion, and national integrity. The films investigated in this paper, from directors such as Sembene, Getino, Solanas and Guzman, are amongst the most culturally significant and politically sophisticated from this movement and which denote the adoption of an independent, often oppositional stance towards commercial genre emanating from the more developed capitalist world. However, despite the contemporary popularity and critical attention enjoyed by films from Asia and Latin America in particular, Third Cinema appears to have lost its momentum. This article wants to bring Third Cinema back to attention. There are difficult and challenging questions Third Cinema posed and continues to pose. This article seeks to suggest new methodologies and redirections of existing ones, but also reread the entire phenomenon of film-making in a fast-vanishing 'Third World', with case studies of the cinemas of Argentina, Chile, Senegal as well as from European Third Cinema movements.

\section{Overview}

There is an endless debate about Third Cinema and its strategies in offering valuable tools of documenting social reality. From the 70s to recent days, appreciation of its value and aesthetics was unfolded through controversial approaches and different views on this 'radical' form of cinema. The idea of Third Cinema was raised in the 1960s as a set of radical manifestos and low-budget experimental movies by a group of Latin American filmmakers, who defined a cinema of opposition to Hollywood and European models. Possibly this new form of expression was coming from three different areas of the world: Asia, Africa and Latin America. At the time these three zones were labelled 'Third World (in some parts and sometimes they still are). Even though scholars such as Willemen explained how the notion of Third Cinema was most emphatically not Third World Cinema, these two concepts have often been confused either voluntarily or accidentally.

As an idea, the roots of Third Cinema came from the Cuban Revolution (1959) and the figure who supported this revolution - Che Guevara. The Brazilian Cinema Novo, where Glauber Rocha provided an uproar with his polemic manifesto titled The Aesthetics of Hunger (July 1965), was part and element of this new wave. It shared roots with certain aesthetics of Italian neo-realism and Grierson's notion of social documentary and ultimately influenced by some Marxist aesthetics. Filmmakers influenced by Latin American documentary include figures such as Fernando Birri, Tomas Gutierrez Alea, and Julio Garcia Espinosa.

The term Third Cinema was invented by the Argentinean film makers, Fernando Solanas and Octavio Getino who had produced and directed the most important documentary for the Third Cinema in the 60's La Hora de los Hornos (The Hour of Furnaces, 1968). At the same time, they wrote an important essay sustaining the radical ideas of Third Cinema: Towards a Third Cinema (1969). The principle characteristics of Third Cinema is really not so much where it is made, or even who makes it, but, rather, the ideology it espouses and the consciousness it displays. In one word we might not be far from the truth when we claim the Third Cinema as the cinema of the Third World which stands opposed to imperialism and class oppression in all their ramifications and manifestations.

The Third Cinema has offered a significant means of documenting social reality through the analysis of documentaries from Argentina, Chile and Algeria and, on the other side of the Ocean, also from Black Independents documentaries for what concerns the British context.

Self-conscious ideological opposition to Hollywood was the first marker of Third Cinema, while identification with national liberation was the next most common theme, at least in the early writings on the subject. The idea of the nation in this discourse, however, always rubs up against globalized Third World identification. On the one hand, the tri-continental definition of radical film aesthetics defies national boundaries. On the 
other hand, if any cinema is determinedly 'national' even 'regional' in its address and aspirations, it is Third Cinema.

The political-cultural trends of the 80s and 90s have demonstrated the need for a definitive reappraisal of the terms in which a radical practice like Third Cinema had been conceived in the 70s: questions of gender and of cultural identity received new inflections, and traditional notions of class determined identity were soon to be seen as a tool inadequate as the forms of struggle that corresponded to them.

\section{La hora de los hornos, The Battle of Chile, Salvador Allende}

The importance of Solanas and Getino is due to both their manifesto about Third Cinema and the striking documentary of 1968, La hora de los hornos. This documentary has a more important place within revolutionary films in pushing the audience into action to subvert imperialism politics through the dynamism of its style and the radical and systematic way that it frames political and ideological issues. From several authors this kind of cinema has been labelled as 'Guerrilla cinema' or 'cinema like a gun' because of the force of their images and of the violence with which the film makers addressed the social and political issues of Latin America. In this work the montage divided the whole documentary into thirteen chapters and three sections. Each chapter is supported by statements, quotations and slogans. At that time La hora de los hornos tried to unfold episodes and characters that as stated by Gabriel aimed to "raise the consciousness of its audience".

La hora de los hornos represents a multi layered form of documentary. The work is a combination of two or more modes of facing social reality. Usually the documentary modes can be ranged within four categories such as expository, observational, interactive and reflexive. Even though lacking in impartiality and so consequently observational mode is absent, the Solanas and Getino film encompasses defiantly expository, interactive and reflexive modes of documentary.

La hora de los hornos is divided into three sections: the first 'Neo-colonialism and Violence' relates Argentina to the European influences; the second section 'An Act for Liberation' explains the opposition struggle during Peron's exile; in the third section 'Violence and Liberation' we can alternately appreciate documents, interviews and quotations framing the path to a revolutionary future for the people of Latin America. That was the period of the tri-continental revolution supported by figures such as Frantz Fanon, Ernesto Che Guevara and Ho Chi Minh.

The use of spoken and written commentary directly addressed to the audience definitely embraced the notion of 'Guerrilla Cinema', where the spectator is called to act against Imperialism.

From an editing point of view, recorded noise and distortive music play a discursive and demystifying role. Minimalistic avant-garde aesthetics not only is appropriate to the exigencies of film production in that particular context but also reflects artistic strategies.

The Third Cinema was trying to develop a new web of production and distribution away from the mainstream channels. In this direction La hora de los hornos worked in finding a way out from censorship with a creation of an underground system of distribution. Sometimes the screenings of Solanas and Getino had to be protected by militant armed guards to avoid the risk of government retaliation.

La hora de los hornos has an undoubtedly timeless value since its release because of its attempt to frame an ideological-political argument. The politics used by US strategies in the 60s, 70s and 80s as described by the documentary of the two Argentinean filmmakers indeed is not too different from the strategies raised up by the same US administration in the last few years of post-colonialism and savage wars under Bush's reign. With no surprise, La hora de los hornos could be screened to denounce the crisis that affected Argentina in 2000, due to economical struggles provoked by IMF and its 'bizarre' financial strategies without losing its force.

Solanas and Getino contributed greatly in building one of the most important columns and reason of debate within Third Cinema such as the notion of national culture and identities. Enhanced by this concept of specific national roots that comes from African, Asian and Latin American Third Cinema, La hora de los hornos has mirrored the pursuit in avoiding the industrial-political domination of Hollywood.

La hora de los hornos is probably the most influential documentary ever released in Latin America, because 
it is not only useful as a device to understand the culture and political discourses of the late $60 \mathrm{~s}$ but it is still meaningful to decipher the actual social problems in the Latin America continent.

In the manifesto 'Towards a Third Cinema', Solanas and Getino stated their idea of goals to be achieved through Third Cinema: "The anti-imperialist struggle of the peoples of the Third World and of their equivalents inside the imperialist countries constitutes today the axis of the world revolution. Third cinema is, in our opinion, the cinema that recognises in that struggle the most gigantic cultural, scientific, and artistic manifestation of our time, the great possibility of constructing a liberated personality with each person as the starting point - in a word, the decolonisation of culture."

Years later (2004) in Latin America another important documentary was released by Patricio Guzman Salvador Allende, a documentary which tells us about the life and death of the socialist president of Chile, who in 1973 was killed or pushed to commit suicide (still a lot of controversy on this point, although the latter seems the most accepted version) by both Pinochet and CIA in a coup d'etat.

As Guzman did in 1977 with The Battle of Chile, a three-part documentary about Chilean socio-political life in the early 70s, Salvador Allende has a particular mode of production that creates an epic work poised between direct and dramatized, immediate and mediated modes of describing historical and dramatic events.

Both movies through the use of a voice-over mark the differences between these features and those concepts of direct cinema.

Although the sequence shots and the mobile framing, reframing, focus shifts, and movements within the image could code the film as "direct", the voice-over reinscribes the filmic discourse as an authored discourse.

\section{Third Cinema in Africa: past and present}

In a continent like Africa, due to the long-term difficult situation of the cinema industry, the first point on a filmmaker's agenda is looking for funds, and this need shows how the Third Cinema's struggle for survival is still harsh. I will take into account specifically the period in which Third Cinema was born in Africa and specifically with works by Ousmane Sembene such as Ceddo, Emitai and Xala.

"When one creates one does not think of the world; one thinks of his own country. It is, after all, the African who will ultimately bring change to Africa." (Sembene)

It is in this quote that is embedded most of the philosophy with which Ousmane Sembene realised and supported, in Senegal, the project of Third Cinema in Africa.

He encountered several troubles with Senegal censorship; usually his works have been either delayed or forbidden. Sembene often portrayed Africa as a land peopled with oppositional groups, who fight for their independence and for their cultural identity. His work, Ceddo (1977) represented one of the most important pieces of Third Cinema in Africa. The title itself was quite critical of the colonization process, in fact the translation in English means 'outsider'. This word wanted to portray African struggles in resisting the conversion to Islam, and to a certain extent also Christianity. In Sembene words "The Ceddo is a lively mind or spirit, rich in the double meaning of words and knows the forbidden meanings. The Ceddo is innocent of sin and transgression. The Ceddo is jealous of his/her absolute liberty" (Sembene).

The film is set in a traditional African village during the period when North African Arabs were building Islamic colonies all over Africa. In the feature, the village included three symbols of 'foreignness' which invades African spirituality: a European trader, a Catholic priest and an Arab Moslem. The movie shows the desire of colonization of African culture by these three different icons, faced by the local 'outsiders' and just among these 'outsiders' we find 'Ceddo'. The feature is dominated by icons which represent the opposing cultures that struggle to survive.

For a long time African Third Cinema was also the 'cinema of silence' whereby the silence witnessed the African spirituality to be protected and filmed without any form of invasion. Even though the first part of Sembene's career was characterised by this element of silence as, for example, featured in Emitai, Ceddo lost this cinematic approach to the African culture.

The silence in Third Cinema produced in Africa and specifically by Sembene seems to have two levels of reading: firstly, tradition is instinctual and articulation is not necessary for active opposition to the external 
religions; secondly, the silence echoes the reverence for traditional culture which in spite of attempts of imperialism remains bound deeply to African identity.

Recently, a new form of Third Cinema coming from the African continent is that of video-film features. According to Ukadike, it's useful to underline how almost all the video-films showing Ghanaian and Nigerian contemporary living are painted with "ostentatious allure". It seems the representation of African culture seen through naked breasts of village women have ended; instead today we see high-profile upper class, especially businessmen and women.

Even though this new form of cinematic expression embraces a certain wealthy life style, at the same time these new video-films are filled by national heroes, local and famous songs, in MTV style, and an iconography of identity that is hardly fairly portrayed either by mainstream Hollywood cinema or European cinema. Thus these new forms embrace Third Cinema strategies of analysis, whereby images, sounds and music function as frames to channel the struggle against past and contemporary forms of post-colonialism.

The debate among African filmmakers nowadays seems to be about the uniqueness of their cinema and to find ways of differentiation from Euro-American cinematic modes of expression. The aim pursued today by most of Third Cinema African filmmakers lies in fighting against all the obstacles that are retarding the development for this continent, trying to find a common thread between post-colonialism, film and local identities.

\section{Third Cinema within a European border: Black Independents}

Third Cinema includes an infinity of subjects and styles so this form of cinema can be practised anywhere, opening the way towards new formulations of Third Cinema also within Europe. From this point view and from the diasporas' element in it, we can analyse the importance of the Black Independents operating in the UK which helped to create a new notion of Third Cinema.

The importance of Third Cinema as a medium produced also within European boundaries is raised by the position of the Black Audio Film Collective formed in the 80s within UK borders. Their struggles in finding a new form of expression under Thatcherism, Black Audio Film Collective assumed a fundamental role in the presence of Third Cinema in a reality of globalization just like nowadays. Thus talking about Third Cinema as cinematic expression coming only from the three areas of Latin America, Africa and Asia means to dismiss the powerful impact on the European boarders of this cinematic reality. Black diaspora expressed in the last few years new groups of ethnicity all over Europe such as Paris, London, Madrid and it would not be fair to not consider those realities as potential expression of the same thematic and aesthetics raised in the past by the three different areas previously mentioned.

As reminded to us by Reece Auguiste, an interpreter of the Black Audio Film Collective, Third Cinema in Britain through this group needed to find its own distinctiveness. Even though the filmmakers who represented Black Audio Film Collective are working now as individual artists rather than members of that group project, the importance of a new alternative visual grammar is fundamental to address the needs of this new diasporas generation which deal with the same issues of demarginalization as their parents once did in their old lands.

It's also by supporting groups of filmmakers such as those coming from Black Audio Film Collective's experience that it will be possible to redefine the boarders and the tools of Third Cinema in these years of migration, globalization and in one word Diaspora. The multiplicity of identities and histories needs to be displayed through subjects able to read a dialogue between new technologies, class gender and a mix of languages.

\section{Third Cinema as 'third space'}

Third Cinema may relevantly result as third, the 'third space' which displaces the histories and needs that constitute it and sets up new structures of identity, new political initiatives, which are inadequately understood through the actual mainstream channels of production and distribution.

Due to the changing multiracial and multicultural world reality, Third Cinema must reinvent itself in terms of gender, class and geographical identity and consequently in terms of narrative structure and aesthetics.

The challenge between those cosmopolitan images and the struggle of local identity continues to move film 
authors looking for new ways to co-produce new Latin American, African and Asian cultural identities through collaborative practices that have as their ultimate aim not the removal of the local but a meaningful relocation of it in the global community.

As happened also for Solanas, the Third Cinema needs to configure itself as authorial icons representing their respective national culture within the global market, without losing their status of oppositional figures to the mainstream cinema, without losing the local identities either coming from the Third World area or from a European context.

These concerns to define a necessary and new form of Third Cinema must not leave behind the primary concerns in the production of 'revolutionary films'. The need of Third Cinema is undoubtedly a call for social and cultural transformation. Even though historical contexts and aesthetic responses may change, its mandate to face post-colonialism and to protect local identities still holds. Obviously the present aim of Third Cinema, ignoring geographical borders, is to continue in seeking its own place in a global context. Third Cinema is not the cinema of the Third World but is the cinematic expression of the desire to express ourselves and our identities, although a general tendency of politics and culture is pushing towards a way of homologation and annulment.

\section{References}

\section{Bibliography}

Alberto E., Díaz López, M. 2006. The Cinema of Latin America. Wallflower Press, London.

Armes, Roy 1987. Third World Film Making and the West. University of California Press, Berkeley.

Barnard, Tim 1986. Argentine Cinema. Nightwood Editions, Toronto.

Burton, Julianne 1990. The Social Documentary in Latin America. University of Pittsburgh Press, Pittsburgh.

Downing, John D. H., 1987. Film and Politics in the Third World. Praeger, New York.

Gabriel, Teshome H. 1982. Third Cinema in Third World. UMI Research press, Michigan.

Guneratne A., Dissanayake W. 2003. Rethinking Third Cinema. Routledge, New York.

Karen, Alexander 2000. "Black British Cinema in the 90s: Going Going Gone" in Robert Murphy British Cinema of the 90s. BFI, London.

Loizos, Peter 1993. Innovation in ethnographic film. Manchester University Press, Manchester.

MacDonald K. Cousins M. 1996. Imagining Reality: The Faber Book of Documentary. Faber and Faber, London.

Martin, Michael T. 1995. Cinemas of the Black Diaspora: Diversity, Dependence, and Oppositionality. Wayne State University Press, Detroit.

Nichols, Bill 1991. Representing Reality. Indiana University Press, Bloomington.

Pines J. Willemen P. 1991. Questions of Third Cinema. BFI, London.

Rocha, Glauber 1995. "The Tricontinental Filmmaker: That Is Called the Dawn" in Johnson and Stam Brazilian Cinema, pp.76-80. Columbia University Press, New York.

Rosenthal, Alan 1988. New Challenges for Documentary. University of California Press, Los Angeles.

Renov, Michael 1993. Theorizing Documentary. Routledge, London.

Schnitzer, J\&L. 1973. Cinema in Revolution - The Heroic Era of the Soviet Film. Secker \& Warburg.

Stam, Robert, Toby Miller, 2000. Film and Theory: An Anthology. Blackwell Publishers, Oxford and Malden. 
Swann, Paul 1989. The British Documentary Film Movement, 1926-1946. Cambridge University Press, Cambridge.

Wayne, Mike 2001. Political Films: The Dialectics of Third Cinema. Pluto Press, London.

\section{Filmography}

Los Olvidados (Mexico, 1950)

Ultramar Films

Producer: Óscar Dancigers, Sergio Kogan, Jaime A. Menasce

Director: Luis Buñuel

$\mathrm{B} / \mathrm{W}, 85 \mathrm{~min}$.

Terra em transe (Brazil, 1967)

Mapa Filmes

Producer: Glauber Rocha

Director: Glauber Rocha

B/W, 106 min.

La hora de los hornos (Argentina, 1968)

Grupo Cine Liberacion, Solanas Productions

Producer: Fernando Solanas, Edgardo Tallero

Director: Fernando Solanas, Octavio Getino

B/W, 260 min.

Barravento (Brazil, 1969)

Iglu Filmes

Producer: Rex Schindler

Director: Glauber Rocha

B/W, 78 min.

Emitai (Senegal, 1971)

Filmi Domirev

Producer: Ousmane Sembene

Director: Ousmane Sembene

Colour, 103 min.

Xala (Senegal, 1974)

Films Domireew, Ste. Me. Production du Senegal

Producer: Paulin Vieyra

Director: Ousmane Sembene

Colour, $123 \mathrm{~min}$.

The Battle of Chile (Chile, 1977)

Equipe Tercer Ano Instituto Cubano de Arte e Industrias Cinematográficos

(ICAIC)

Producer: Chris Marker

Director: Patricio Guzman

$\mathrm{B} / \mathrm{W}, 300$ min.

Ceddo (Senegal, 1977)

Ousmane Sembene

Producer: Ousmane Sembene

Director: Ousmane Sembene

Colour, 120 min.

Handsworth Songs (UK, 1986)

Black Audio Film Collective

Producer: Lina Gopaul 
Director: John Akomfrah

$\mathrm{B} / \mathrm{W}, 61 \mathrm{~min}$.

Salvador Allende (Chile, 2004)

JBA Productions, Les Films de la Passerelle (co-production), CV Films (co-production), Mediapro (co-production), Universidad de Guadalajara (co-production), Patricio Guzmán Producciones S.L. (coproduction), Centre National de la Cinématographie (CNC) (participation), Canal+ (participation), Westdeutscher Rundfunk (WDR) (participation), arte (participation), Yleisradio (YLE)

Producer: Jacques Bidou

Director: Patricio Guzman

B/W, Colour 100 min.

\section{Author Information}

Nicola MARZANO graduated with an MA in Film and Television Studies at Dublin City. He is a freelance writer based in the Dublin area. 